evacuation of the nterus. It was a great disuppointment to me to find that this sign. which I hoper would be a good indication, had failed. The only point on which I disagreed with Dr. Wetherill is that $I$ do not attach to the percentage of the ammonia coefliciont the same degree of significance that he has attached to it in his paper.

Dr. H. G. Methemir, Denver: I have no final solution of the problem to offer. It is in a process of evolution and its solution must depend on the members of the profession and their laboratory co-workers. I did not intend to convey the inipression that I rocrarded the percentage of the ammonia coellicient as a sole and final factor which should decide whether or not the uterus should be cmptied. Like Dr. Fry, I do not accept the statement of Dr. Williams as the last word in this mater. Probably Dr. Williams himself may be inclined to modify his views later. Taken with other things, however, it has a great deal of significance. I think that the character of the toxemia is indicated much more by the state of the blood and the blood tension as shown in the eyegrounds and otherwise, and I regard the condition of the ryes and the coopration of an expert ophthalmologist as most important in making the diagnosis and in deciding on the course of treatnont to be adopted.

\section{A SUMMER CAMP FOR THE TREATMENT OF SICK BABIES.*}

WALTER GRAHAM MURPIIY, M.D. IIARTFORD, CONX.

In the treatment of summer diarrhea in children, artificially fed, it is generally agreed that there are three jmportant requisites, namely, clean milk, fresh air, and intelligent care. It is also agreed that in the prevention of diarrhea the utmost vigilance must be observed during the hot months, particularly in cities. How to provide all these conditions is one of the problems in medicine, the solution of which is imperative.

'This paper' has to do with the efforts of the Hartford (Conn.) Medical Society to solve this problem in its locality. During the summer of 1907 a camp was maintained in one of the city parks by a committee of the society. This camp was suggested at a meeting of the milk commission of the Hartford County Medical Association. It is easily seen that the production of certified milk is not sufficient alone to materially reduce the high mortality of diarrhea among the children of the poor. The price is prohibitive. Those who can afford to pay fiftecn cents a quart for milk can conveniently remove their children to the country or seashore during the bot months. Those who, from necessity, must remain in the city, and can not procure certified or other highgrade milk, are the very poor. Some, it is true, realizing the importance of clean milk, obtain it at the sacrifice of other things, but many can not. It is to reach the latter class of people that the hospital was established. Milk stations and laboratories for distributing certified milk were carefully considered, but it was the opinion of all that the best results were to be obtained by a hospital assuming entire control of a patient, night and day, during his illness.

As a result of this opinion at a meeting of the Hartforr Medical Society a committee of ten was appointed with authority to construct and maintain a summer hospital for the care and treatment of sick babies. 'The committec was given authority to collect money in the name of the society for the support of the hospital.

* Read in the section on Niseases of Children of the American Moti al Assoriation, at the [Oity-ninth Annual Session, bejd at Chitago, June, 1908 .
P'rmision was obtained from the city park board to locute a tent hospital on Riverside Park, and an appeal for money was made throtgh the daily papers.

Riverside Park, as its name implies, is a park on the bank of the Connecticut River. It is not an ideal location for a camp. 'The park is very largely made ground, somewhat low, and twice a year at least is under water from river freshets. On the east side it borders the river, and on its west is a railroad freightyard. It was certainly a severe test for the efficiency of an outcloor hospital. This park was selected because of its nearness to the tenement district whose babies it was designed to treat and to whose mothers it was desired to demonstrate that cleanliness for babies, pure milk, and fresh air would accomplish results.

In the construction of the hospital four tents were used. One was a ward-tent thirty feet long and fifteen foet wide, with six-foot side walls and thirteer-foot ridge. This tent loeld, with some crowding, twentyfour babics. Behind the ward-tent and connected with it by a corered passage, was the diet-tent, twelve by foulteen feret. There the babies' milk was prepared and inctruction given to the mothers of the sick children in the methods of handling clean milk and of making simple modifications. Fach mother had these instructions before taking her baby home. Behind the diettent stood a tent nime by nine feet, containing the boiler which furnished the hot water. and at one side was a tent twelve by fourteen feet used as a nurses' dormitory. All the tents, except the boiler-tent, were floored. The furnishings of the wart-tent were two long tables two fect in width, which held baskets for the babies. Each basket was covered by a hood of mosquito-bar. All woodwork was painted white. In the diet-tent were a sink with hot and cold water, a rofrigerator and a table for proparing foor for the pationts. All the tents were lighted loy electricity.

The hospital was opened July 1.5 with accommodations for twelve patients, and two nurses in attendance. Iater twelve more baskets were addor and three nurses. Our nurses worked under decided disadvantages. The dormitory as arranged was not practical for sleepingquarters during the day. A room was provided and meals furnished up-town.

The attending staff consisted of members of the society. There were six attending physicians, a bacteriologist, who kept a careful oversight of the milk supply, and a pathologist. The members of the genera] committee having the work in charge acted as consultants.

According to Dr. Williams' report as secretary there were treated, up to the closing of the hospital on September 15 , sixty babies. The average number per day was twelve; the average length of stay ten days. During the hot periods all twenty-four beds were filled; and on one day in August there were twenty-five patients, and eight were turned away from lack of room. Most of the patients ( 60 per cent.) came in for summer diarrhea; 30 per cent. were suffering from marasmus or severe malnutrition; 7 per cent. had gastrointestinal indigestion withont diarrhea; 10 per cent. had marked rickets: 5 per cent. had pneumonia; while meningitis, malaria, pericarditis and cretinism claimed one case each. The death rate was comparatively low, considering the severity of the cases treated, most of the deaths occurring in cases in which diarrhea was grafted on a previous malnutrition or rickets. There were twenty deaths, or 33 per cent. mortality, 
inchaling all cases. Derducting foum this the patient: that entered the hospital morihund and died within the fires twenty-four houm. the death rate was is por (ent)

The expense of the hospital was met by public sulpseription. Areording to the peport of the treasures. D). - brams, the total expense llas $\$ 1,619.01$. Of this amount $*$ tris.96 was lor equipment. tents, plumbing and rarpenter work; $\$ 2 .+42$ for furmishings, berl-sheeting. homsohold utensils. ete.: \$20s.t? for maintemance. laundry, tolephone and help: $\$ 200$ bor food, including wroceries, iee. coal and medieme: $\$ 116.20$ for nurses

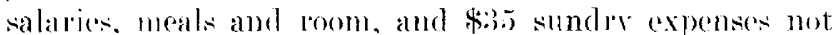

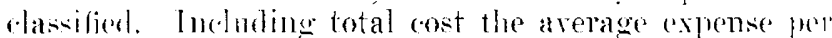
day for anch patient was $\$ 2.2 \%$. Deducting the enst o! expiement and fomishings and not allowing for deprecelation. which is als umknown guantity, the arepage cost pee day lor each pationt was $\$ 1.1 \%$.

'The commitee feels that the societs mar congratulate jtrelf on the sueress of the hosprial. and on the interest which it amosed in the community. The well-to-do gallied most eorlially to its support and gave help and money lreely, and the east side showed its interest by (oming to the hospital in sach cowds that the tent: had to he roped aromerl to protect them.

such, in brief outlime, is the resiut: of our first real": unclertaking.

Doring the present summer the same geveral phan of work is to be eontinued as that of last yeals. There will be adderl another ward, thus allowing a total alecommorlation of torty patients. The mursing stall will

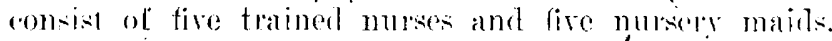
'The murey maids will be trainerl in the' care of bahies moter ordinary eonditions. They will be taught the? rules of infant hequene and the are and preparation of food. The committer also hopes to he ahle to give to the mothers more ardengate demonstrations of the alle of milk and bottles.

On aceount of lle increased fores of murses and the diffiralties experioned last you in finding suitable accommodations for boald and rooms nealle the lospital, and also the experese and incomrenienee of sending ont the lammlry. the committer lias purehatsed a portable house, to be used at a dormitors, dining-ronm and kitelen for the morses. and in which the laumber work ran he done.

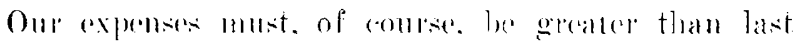
yeals.

The eommitue does not put forwart the irlea of a summor cante with any elaim of originality. In the important work of education and in the alleviation of the siek. this camp simply demonsthates a method which may be employed. It is modest in its construetion and inexpensive to maintain. It offers the atrantage ore? regularly established hospitals that it an he erected on any plot of ground where there is a water supply and Trainage. and further. it fulfills its function as an object-lesson and means of education better than any isolated hospital ean possibly do. It is in the open where those who pass must see its work and its a $\mathrm{im}$.

$$
\text { i.s Pratt Street. }
$$

\section{DISCUSSION}

DR. I. H. Masox Kxox. Baltimore: T haw been interested in work of this character for several years and am glad to see that it is becoming more general. In Baltimore we found that the terrific thunder storms which we sometimes have there matde tents impracticable for sick babies. Considering the short rluration of time these babies stay in the hospital, there should he trained nurses and physicians to care for the bubies whon they are returned to their homes. We found at Homt IIilson that unlesis. after the babies were returned to their lumes. we eould give them pure milk of exactly the quality we hat at the hospital and supply the proper nursing moch of our summer work at Mount Wilson was thrown away. If tlyese children can be returned to their homes with a mother who understands better how to care for them and a trained nurse to risit them in their homes and give necessary in sruetions, the result from the summer amp treatment will be very much better.

DR. Ionx M. Brikh. Milwaklee: I want to give a little reriew of the work that is being planned in Milwaukee. A Yeall awo one of the women's rlubs became interested in the deatls rate among children under 5 yoars of age. The death rate was shown to be 40 per cent. of the total death rate in rhiblen under 5 years of age. We had the highest death rate among children mider s yeal's of any city in the Lnited States mutsicle of Pittsbure. The matter was laid before the city (w) wheil. which apponpriated $\$ 3.000$ for the recetion of a sanitaritum or pavilion to les loeated on the lake slowe. It is about 4l) feet wide and so feot long. It faces Lake Michigan on the east. The main entrance is in the middle, and at the rear of the main floor is the administration room. then a room for nurses, a diet kitchen, an ise-box, a bathoon with a set of six infants tuls and the lavatory. Then there is a space entirely open and surrounded by a railing. Curtains "an be raised in time of wind to proted this spices. Ilammorke are hung hele and ten litte cribe placed in the rear. 11 . hate already ratiod by a bitte work about $\$ 1,000 \mathrm{for}$ the maintomatner of this work for this smmmer. the ideat being to "all the attention of the public to the fact that there is here a vital problem. Let us lecome awake on this subject and realize that the balies under is yeals of age should be better cared for.

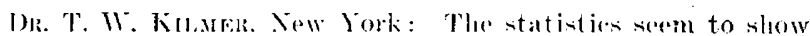
a strikingly high motality 3:3.5 !ere cent. In New lork in our ost-patient depatment our statisties are so much lower Iham that. that 1 wonk like to know if these babies were practically moribund when bronght in.

DR. II. C. MCRPly, Hartford. (mon.: I won't guarantee the statiotien. We had a very busy summer. Whether they are striclly aceurate or not J do not knew. But taking them as they are and dorlueting the cases of patients who came in moribund, we have a mortality of about 18 per cent. It is unfortunate that phinicians will molod on us ases in which there is alsolutely wo hope. If I am not mistaken. the mortality of the floating hompitals is alout the same as ours. Only desperate cases are sent to these hospitals: the mortality must be ligher than other institutions. Our experience was that we wot more money than we needed.

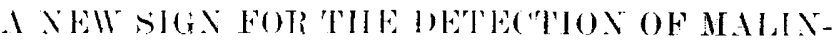

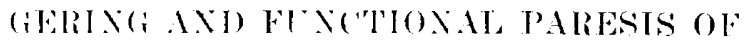 THE Joll ER FATREMITISS.}

$$
\begin{aligned}
& \text { (. F. IIONER, M.D) } \\
& \text { (nevelaxb. }
\end{aligned}
$$

Tle sign I wish to describe is one which I have emmoyed for the past two rears. Although the cases ulserved number only four, I feel justitied in attaching wreat importance to the sign because it is dependent on a normal function, which $\mathrm{I}$ find always exhibited in healthy persons and invariably present in the sound ley of patients suffering from hemiplegia or paresis of one leg due to some pathologic lesion.

If a normal person, lying on a couch in the dorsal position, be asked to lift the right foot off the couch with the leg extended, the left heel will be observed to dig into the couch as the right leg and thigh aro elerated. If you place your hand under the tenclo Achillis 